\title{
Engaging With Living Waters: An Inquiry Into Children's Relations With a Local Austin Creek
}

\author{
Lene Saint-Orens and Fikile Nxumalo
}

Lene Saint-Orens is the founder and executive director of Wholesome Generation, a nonprofit educational institute. Through partnership-based programs at her five-acre community school, Lene engages youth and families in holistic and sustainable learning experiences including outdoor education and community engagement. Email: lene@wholesomegeneration.org

Dr. Fikile Nxumalo is an assistant professor of early childhood education at the University of Texas at Austin, where she is also affiliated faculty with African and African Diaspora Studies and Native American and Indigenous Studies. Fikile's research interests center on environmental and place-attuned early childhood studies that are situated within and responsive to young children's uneven inheritances of anthropogenic, anti-black, and settler colonial worldings. This scholarship, which is published in journals including Environmental Education Research, Contemporary Issues in Early Childhood, International Journal of Qualitative Studies in Education, and Environmental Humanities, is rooted in perspectives from posthuman, Indigenous, and Black feminisms. Email: fnxumalo@austin.utexas.edu

This article focuses on the inclusion of local environmental education for a class of kindergarten children in Austin, Texas. The purpose is to inspire educators to include local waterways as a compelling source for children to learn alongside environmental challenges in their immediate contexts, to learn how to live in reciprocal relations with water, and to care for water as essential to all life on earth.

Key words: water inquiries; reciprocal relations

\section{Water Movements and Pollution}

At our community school, nestled on five acres of land in Austin, Texas, and surrounded by a large creek bed, the children regularly engage with the creek water, searching for and inquiring about living species, the environmental impact of local weather changes, and pollution by the waste that is washed in with the change of seasons and weather.

On a warm fall day, soon after we arrive, children begin to notice the changes in the creek since our last encounters. "The water looks dirty today," A. notices.

L: "Is the water dirty, or are we moving the dirt when we walk in it?"

During these morning walks through the landscape, the children notice the waste that is in the water and along the creek bed. The children are concerned about the waste, which includes glass and plastic bottles, cans, and clothing, among other discarded household items. We regularly collect this waste, filling up multiple garbage bags, but it seems never ending. Often the children express concern about what the waste is doing to the crawfish and deer that co-inhabit this area. For example, after we find deer prints along the creek bed, one child expresses that the deer is "happy that we cleaned up the garbage."

The impacts of climate and water are intimately entangled with children's lives in Texas. For example, the class recently experienced the local impact of Hurricane Harvey. Harvey was

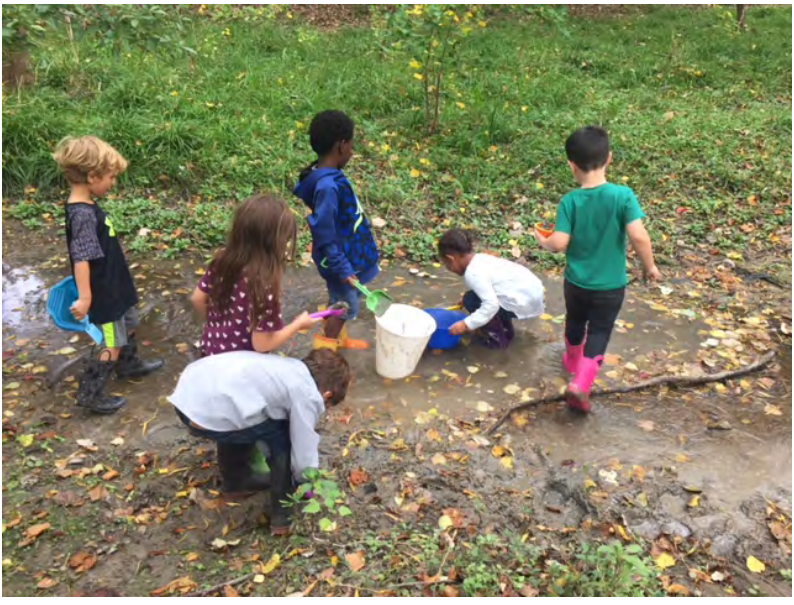

Figure 1. Children's inquiries with water. Photo credit: WG educator Libby Berg. 
a devastating tropical cyclone that occurred in August of 2017, causing widespread flooding in the Houston, Texas, metropolitan area. Here in Austin, located just a few hours west of Houston, we also experienced very heavy rains and areas of severe flooding. During this time, children inquired about the rise in water level at the creek (which we had to observe from afar at times) and wondered about what would happen to the deer that frequent the creek. They also closely watched educators raise the bee hives that we keep at the school higher off the ground so as to avoid potential flooding of our bee friends. They also noticed how the heavy rain increased the waste in and along the creek, and how it changed the look of the creek. We wondered alongside children about whether the rains brought more pollution to the creek. One day, the children and educators noticed with concern that alongside some areas of the creek there was a shiny oily-looking liquid. We continue to grapple with ways to make connections with the children on the entanglements of climate change and water events, but the children are already experiencing these events, being affected by them, and learning how they affect other human and more-than-human life.

The hurricane event also led the children to ask many more questions about the water cycle and especially around the accumulations of waste at the creek after heavy rains.

"Where does the trash come from?" asks A.

We wonder aloud with children if the creek is connected to other waters where people place trash in the water. We wonder about creek water movements with rain. We wonder how we might respond to this trash that never goes away.

"We should always pick up anything that could harm the creek," suggests N.

While there are several areas of concern to the children in this inquiry, the creek is also a source of pleasure and wonder to the children. Some children are interested in searching for leeches, while others are interested in collecting leaves or swinging on a tree limb. One day one of the children found a spider web built into an abandoned cement brick alongside the creek, and we all slowed down and stopped for a long time to admire the beautiful web.

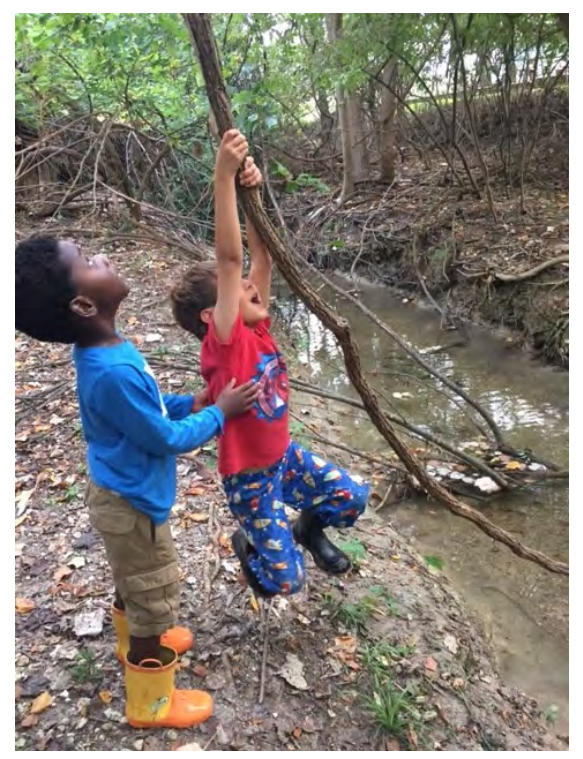

Figure 2. Children swing on tree limb. Photo credit: Lacey Marie Photography.

\section{Life Within Water}

Every place is tended to by waters that cycle through the earth's hydrological systems and make their way back continuously to the ocean. And these watery arteries link us explicitly to the oceans that cover the majority of the globe. It is crucial, in times of environmental / socioecological upheaval, to underscore and impress the interconnectedness of lands, waters, space, people, and time. (Todd, 2017, para. 4)

After the waters have receded following the heavy rains, we return to the creek. The children carefully analyze the water flow and depth, using their bodies and the objects we find floating in the creek. For instance, some children become interested in following an empty plastic milk jug as it floats down the creek, eventually removing it from the water when it is stopped by a log. The milk jug is added to the waste we pick up that day. As they wade along the creek, at certain points water quickly fills the children's rubber boots, while at other points the water swirls around the bottom of their boots.

At other times, it is the crawfish that invite children's watery inquiries. On 
one day, they admire a small crawfish they caught at the creek bed, and a dialogue ensues about who the crawfish belongs to.

"I think it belongs to our earth and the creek, and we should safely release it to be with his friends," says L.

All the children agree and two children gently release the crawfish back into the water.

"I wonder if we'll see him again?" says A., as they observe the crawfish under water for a while.

The educators wonder with children about the persistence of life amid the waste and pollution in the creek.

\section{Water Drawing}

As a part of the water inquiries, educators often bring journals for the children to express encounters with the creek and creek bed area. We have included the journals in the inquiries because we see them as invitations to the children to slow down and closely notice their embodied relations to this place, as a way for children to document their own learning, as a lively trace of these everyday creek encounters, and as a way to make visible, revisit, and critically reflect on intentional and emergent learning experiences in the creek encounters.

Due to an abundant presence of poison ivy alongside the creek (which the children recognize and point out several times), if children are engaging with the journals as a group (for instance, sometimes we will

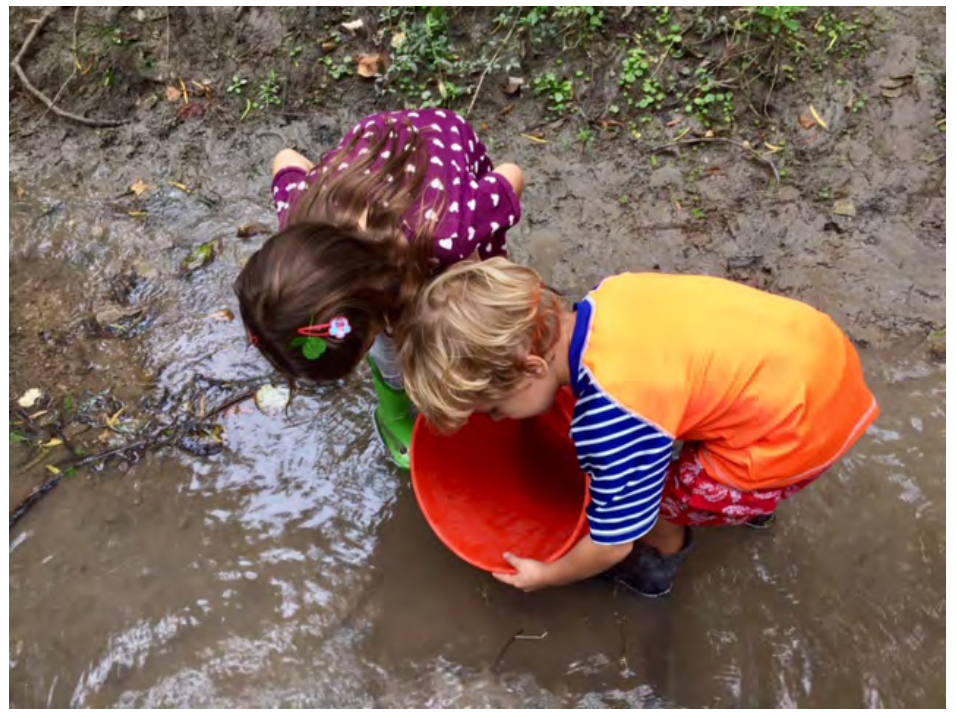

Figure 3. Children releasing a crawfish back into the water. Photo credit: WG educator Libby Berg. read an inquiry-related story by the creek and then invite children to respond to the story in their journals), we place a rug on the ground to sit on.

When we first introduced the journals, which we call water journals, we invited children to draw anything they wished.

L. drew an octopus and wondered: "How will we be sure that the water stays clean for our friends?"

"We will come back to check often and always clean up trash," N. answers. 

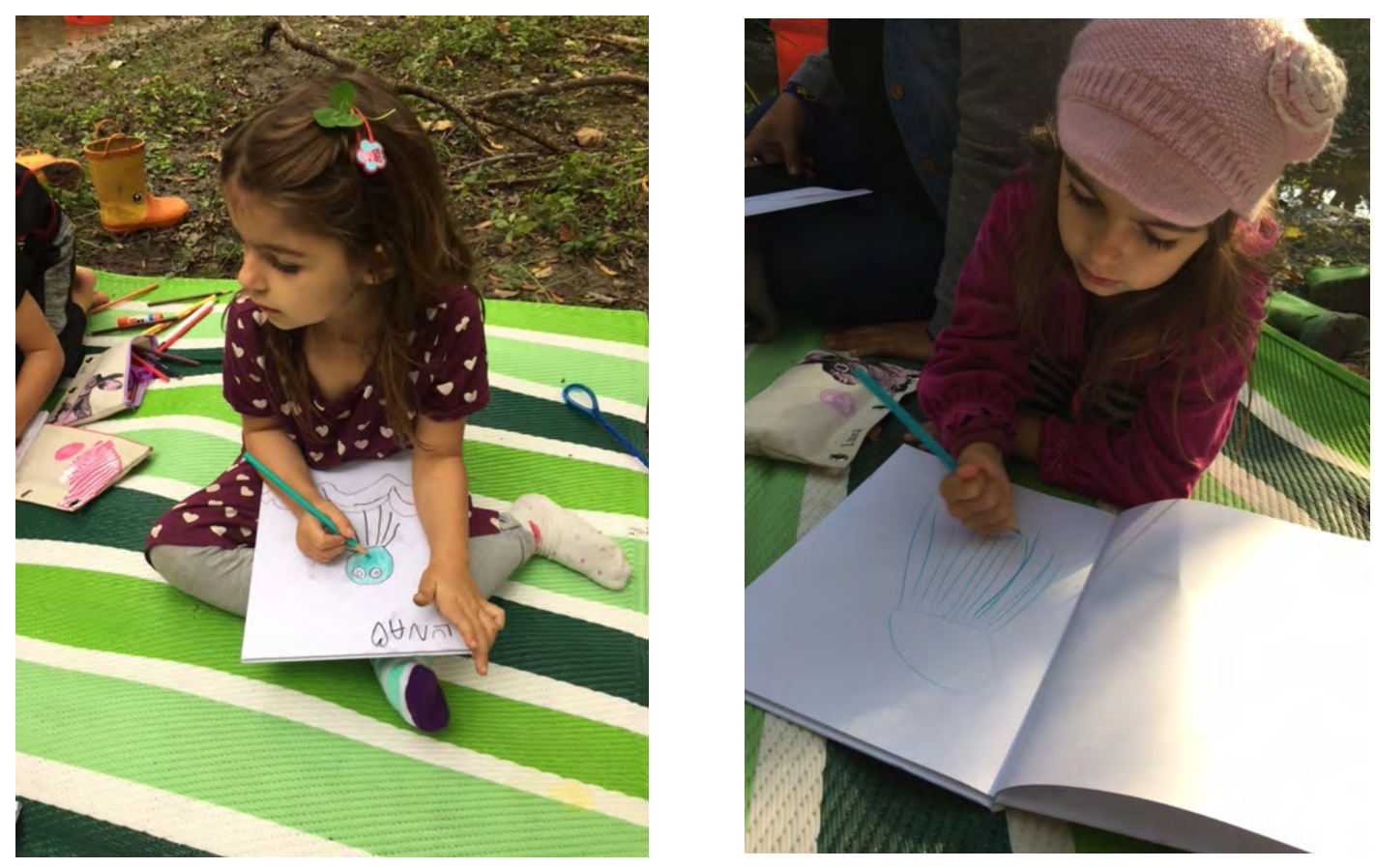

Figure 4. Journalling. Photo credit: WG educator Libby Berg.

\section{Closing Reflections}

Early childhood environmental education scholar Affrica Taylor (2017) brings some important questions for us to think with in this inquiry. She is challenging the pervasive human-centeredness of responses to the current time of unprecedented environmental damage, also known as the Anthropocene:

What lies beyond environmental stewardship responses and pedagogies? How might we reconceptualise our place and agency in anthropogenically-altered and inextricably entangled natureculture world? How might such reconceptualisations inform new kinds of environmental pedagogies that circumvent the traps of always reverting to the script of humans to the rescue?" (p. 1454).

In our pedagogies, we continue to grapple with these provocations alongside children's questions and realizations pertaining to the human impact on the health of the creek and its inhabitants. We are in the midst of responses that include science (water testing), geography (encounters with creek maps), and learning with local Indigenous water relations. For example, we are beginning to learn with Marleen, an Indigenous educator and researcher, about reciprocity, mutual care, and responsibility with water as she generously shares with us the inextricably entangled relations between Coahuiltecan Indigenous people in central Texas and Yanaguana (water of the spirit / spirit of the water). Our pedagogical responses are imperfect, always shifting, emergent, and ongoing. Nonetheless, we remain hopeful about learning alongside children to live in more relational and less human-centered ways in these environmentally challenging times. 


\section{References}

Taylor, A. (2017). Beyond stewardship: Common world pedagogies for the Anthropocene. Environmental Education Research, 23(10), $1448-1461$.

Todd, Z. (2017). Protecting life below water: Tending to relationality and expanding oceanic consciousness beyond coastal zones. American Anthropologist (Public Anthropologies Section). Retrieved from http://www.americananthropologist.org/2017/10/17/ protecting-life-below-water-by-zoe-todd-de-provincializing-development-series/ 